\title{
EVALUATION OF THE RELATIONSHIP OF THE CLIMBING LEVEL OF SPORT CLIMBERS WITH SELECTED ANTHROPOMETRIC INDICATORS AND DIET COMPOSITION
}

\author{
Anna Przeliorz-Pyszczek, ${ }^{A, B, C, D}$ Katarzyna Gołąbek, ${ }^{B, D}$ Bożena Regulska-llow ${ }^{A, D}$ \\ Wroclaw Medical University, Department of Dietetics, Poland \\ A Study Design; ${ }^{\mathrm{B}}$ Data Collection; ${ }^{\mathrm{C}}$ Statistical Analysis, ${ }^{\mathrm{D}}$ Manuscript Preparation; ${ }^{\mathrm{E}}$ Funds Collection \\ Address for coprespondence: \\ Anna Przeliorz-Pyszczek \\ Wrocław Medical University, Department of Dietetics \\ Parkowa 34, 51-616 Wrocław, Poland \\ E-mail: anna.przeliorz-pyszczek@umed.wroc.pl
}

\begin{abstract}
Ahstract Climbing is becoming more and more popular. During 2020 Olympic Games this discipline will be competed for the first time. Individualized diet plays a significant role among representatives of all sport disciplines. The aim of this research was to evaluate the correlation between the level of advancement of sport climbers, selected anthropometric indicators and diet composition. The study involved 36 women and 65 men practicing sport climbing who completed the food record and the survey on the most difficult climbing routes completed. Anthropometric measurements were collected. In the group of men statistically significant, positive correlation between the climbing level and the diet content of fiber, vitamin E, potassium, iron, zinc, and copper, was observed. In the group of women, a statistically significant positive correlation between the climbing level and the participation of vitamin C, potassium, magnesium and copper in the diet was observed. There was a positive correlation of protein, vitamin B2, B6, B12, D, phosphorus, magnesium, iron and copper content, and negative correlation between SFA content per $1,000 \mathrm{kcal}$ of the diet and the climbing level of study participants. No statistical correlation was found between anthropometric parameters and advancement level.
\end{abstract}

Key Worls sport climbing, nutrition, exercise, sports

\section{Introduction}

Sport climbing has become one of the most popular extreme sports worldwide (Ginszt, Goniewicz, Ginszt, 2012). The increasing interest in this form of physical activity has made it an Olympic sport from 2020 on; it will consist of three disciplines: bouldering, speed climbing and lead climbing in a combined format (Lutter, El-Sheikh, Schöffl, Schöffl, 2017).

Bouldering and lead climbing are the most frequently practiced disciplines. Bouldering is climbing up short (usually 4-5 m) technical route, with mats on the ground for safety. Lead climbing is a discipline based on leading 
long routes (usually 20-40 m) with the use of rope and quickdraws clipped to bolts placed in the rock or an artificial wall underneath (Ginszt et al., 2018).

According to the sports classification, climbing is categorized as a "complex sport" (Stanković, Joksimović, Aleksandrović, 2011). Because of the dynamics of the climber's activity and the energetic work of the muscles used, this discipline has aerobic and anaerobic features (Verhosanski, Šestakov, Novikov, Nićin, 1992). An individual nutrition plan, matched with the specificity of training, increases the climber's training capabilities, in addition to minimizing the risk of injury (Neufeld, Meyers, 2018).

Scientific studies involving this group of athletes have so far focused on the physiology of effort (Bertuzzi, Franchini, Kokubun, 2007), strength, and tension of the forearms and fingers (Vigoroux, Quaine, Labarre-Vila, Moutet, 2006) in comparison to the incidence of injuries (Neuhof, Hennig, Schöffl, Schöffl, 2011). The research carried out so far has also focused on determining the anthropometric parameters characteristic for the representatives of this discipline, such as percentage of fat tissue, muscle mass content and hand grip strength to body-weight ratio (Miadenov, Michailov, Schöffl, 2009). There are no studies that aimed to assess the nutritional habits of sport climbers in regard to their level of advancement and to identify the individualized nutritional needs of representatives of this discipline.

The aim of this research was to evaluate the correlation between the level of advancement of sport climbers, selected anthropometric indicators and diet composition.

\section{Material and methods}

The study was carried out in 2016-2017. The data was collected during the Academic Championships of Poland in Sport Climbing, taking place in Sosnowiec, and in the climbing gyms located in Wrocław. This study was approved by the Ethics Committee of Wrocław Medical University. All of the participants have given their informed consent for participation in the research study.

The study involved 101 individuals practicing sport climbing: 36 women and 65 men, 16 to 46 years old, with a climbing level assessed in accordance with the French scale from 5 to $8 b+$. The French scale uses numbers from 1 to 9 , letters a, b and c, and plus (+) sign to grade the degree of difficulty of sport climbing routes, where the lowest numbers mean more difficult walks and the highest mean the hardest climbing routes done so far.

The criterion to qualify for the study was the declaration that sport climbing has been a regular form of physical activity for more than a year. The exclusion criterion from the study was the declaration of only an episodic training on the climbing wall treated as an additional, recreational form of physical activity.

Diet of study participants was evaluated on the basis of a three-day food recording of ordinary period that the subjects filled at home and sent via email. In order to clarify the amount of the consumed portion of the product, the participants received a list of graphic icons of household measures such as teaspoon, spoon, bowl, flat plate, deep plate, mug and glass.

The analysis of the subjects' menu was made using the ESHA Food Processor program with Polish database (Kunachowicz, Nadolna, Przygoda, Iwanow, 2005). The content and percentage of nutrients (protein, carbohydrates, fat) and water in the studied diets, as well as the content of selected vitamins (A, D, E, C, B1, B2, B6, B12, folic acid), minerals (calcium, iron, copper, phosphorus, magnesium, zinc, iodine), and electrolytes (sodium, potassium), were calculated (Table 1, Table 2). 
In addition to the food record, the subjects were asked to complete a survey on the frequency of training and the most difficult climbing routes completed. On the basis of the grade of the most difficult boulder or leading route completed, the participants were assigned to the test groups (Haciski, 2013).

Anthropometric measurements included: body weight, height, the percentage of adipose tissue and water, lean body mass, bone mass, the estimated value of Basic Metabolism Rate (BMR), and the index of visceral tissue in the body (Table 3). Anthropometric measurements of the subjects were collected using the TANITA HR-001 model and the TANITA BC 545 body composition analyzer.

The waist and hip circumferences were measured using a standard measuring tape with an accuracy of $1 \mathrm{~cm}$. The waist was measured halfway between the upper part of the hip bone and the lower curve of the rib. The hip circumference was measured at the widest point below the hip plates, on the buttocks bulge.

The analysis of the obtained data allowed the assessment of the nutritional status of the tested climbers.

The participants of the study were divided into four groups (beginner-intermediate group and an advanced group for each gender) depending on their climbing level and sex in order to determine the correlation between the climbing level, the proportion of macroelements and micronutrients in the diet, and the value of anthropometric measurements. The beginner-intermediate group comprised people whose climbing level, according to the French scale, was between 5 a to $6 c+$, to the advanced group comprised subjects whose climbing level on the French scale was between $7 \mathrm{a}$ to $8 \mathrm{~b}+$.

In order to investigate the correlation between the climbing level with the content of macroelements and micronutrients in the diet per $1,000 \mathrm{kcal}$ of the daily food ration, participants were assigned to one of four groups (beginner group, intermediate group, advanced group and elite) depending on the climbing level. Beginner group included participants whose climbing level expressed in the French scale was between $5 \mathrm{a}$ to $6 \mathrm{a}+$, intermediate for $6 b$ to $6 c+$, advanced for $7 a$ to $7 b+$, and elite for $7 c$ to $8 b+$.

\section{Statistical analysis}

The statistical analysis of the results was carried out in the STATISTICA 13.1 computer program (StatSoft Inc., USA). The statistical significance level for all analyses was established at $p<0.05$. The Spearman rank correlation test was used to assess the relationship between the climbing level of the subjects, the value of anthropometric measurements, participation in the energy diet of macroelements, and the content of vitamins and minerals in the diet. The strength of correlation compounds was assessed as trivial $(0-0.19)$, small $(0.20-0.49)$, medium $(0.50-$ 0.79) and large (0.80 and greater) (Cohen, 1992).

\section{Results}

Table 1 presents a comparison of the content of macro- and micronutrients in the diet of the participants based on their climbing level. In the group of men, a statistically significant positive correlation between the climbing level and the diet content of fiber $(r=0.35)$, vitamin $E(r=0.25)$, potassium $(r=0.25)$, iron $(r=0.32)$, zinc $(r=0.25)$, and copper $(r=0.32)$ was observed. In the group of women, a statistically significant positive correlation between the climbing level and the participation of vitamin $C$ in the diet $(r=0.38)$, potassium $(r=0.38)$, magnesium $(0.38)$ and copper $(r=0.4)$ was observed. 
Table 1. Comparison of macro- and microelements content in the diet of the studied men and women depending on their climbing level

\begin{tabular}{|c|c|c|c|c|c|c|}
\hline \multirow{3}{*}{ Component } & \multicolumn{3}{|c|}{ Men } & \multicolumn{3}{|c|}{ Women } \\
\hline & $\begin{array}{l}\text { beginner-intermediate } \\
\text { group }(n=30)\end{array}$ & $\begin{array}{l}\text { advanced group } \\
\quad(n=35)\end{array}$ & $r$ & $\begin{array}{l}\text { beginner-intermediate } \\
\text { group }(n=22)\end{array}$ & $\begin{array}{l}\text { advanced group } \\
\quad(n=14)\end{array}$ & $r$ \\
\hline & $\mathrm{x} \pm \mathrm{SD}$ & $\mathrm{x} \pm \mathrm{SD}$ & & $\mathrm{x} \pm \mathrm{SD}$ & $\mathrm{x} \pm \mathrm{SD}$ & \\
\hline Energy (kcal) & $2543.0 \pm 565.9$ & $2720.3 \pm 741.7$ & 0.08 & $1882.3 \pm 402.9$ & $1953.40 \pm 402.9$ & 0.05 \\
\hline Protein (g) & $110.8 \pm 34.7$ & $125.7 \pm 49.6$ & 0.15 & $71.6 \pm 17.5$ & $74.41 \pm 17.5$ & 0.10 \\
\hline Protein $\left(\mathrm{g} \cdot \mathrm{kg}^{-1} \mathrm{BW} \cdot\right.$ day $\left.^{-1}\right)$ & $1.6 \pm 0.5$ & $1.74 \pm 0.6$ & 0.14 & $1.3 \pm 0.3$ & $1.3 \pm 0.42$ & 0.05 \\
\hline Carbohydrates (g) & $311.5 \pm 80.5$ & $332.6 \pm 87.5$ & 0.15 & $254.7 \pm 59.0$ & $270.99 \pm 59.0$ & 0.11 \\
\hline Carbohydrates $\left(\mathrm{g} \cdot \mathrm{kg}^{-1} \mathrm{BW} \cdot\right.$ day $\left.^{-1}\right)$ & $4.4 \pm 1.2$ & $4.6 \pm 1.3$ & 0.12 & $4.6 \pm 1.2$ & $4.7 \pm 1.4$ & 0.03 \\
\hline Fibre $(\mathrm{g})$ & $27.1 \pm 13.4$ & $33.2 \pm 11.4$ & ${ }^{*} 0.35$ & $27.3 \pm 11.4$ & $30.1 \pm 11.4$ & 0.24 \\
\hline Lactose $(\mathrm{g})$ & $15.5 \pm 16.4$ & $12.3 \pm 8.4$ & -0.02 & $10.0 \pm 6.2$ & $8.3 \pm 6.2$ & -0.18 \\
\hline Fat (g) & $100.9 \pm 36.5$ & $107.5 \pm 46.5$ & 0.04 & $72.9 \pm 20.6$ & $70.1 \pm 20.6$ & -0.05 \\
\hline Fat $\left(\mathrm{g} \cdot \mathrm{kg}^{-1} \mathrm{BW} \cdot \mathrm{day}^{-1}\right)$ & $1.4 \pm 0.5$ & $1.48 \pm 0.6$ & 0.03 & $1.3 \pm 0.4$ & $1.2 \pm 0.5$ & -0.08 \\
\hline SFA (g) & $36.3 \pm 10.9$ & $37.0 \pm 18.0$ & -0.06 & $27.1 \pm 9.6$ & $24.7 \pm 9.6$ & -0.07 \\
\hline MUFA (g) & $37.5 \pm 15.4$ & $40.7 \pm 19.9$ & 0.07 & $25.3 \pm 8.2$ & $24.9 \pm 8.2$ & -0.07 \\
\hline PUFA (g) & $16.9 \pm 9.6$ & $18.7 \pm 9.8$ & 0.12 & $12.9 \pm 5.7$ & $13.2 \pm 5.7$ & 0.07 \\
\hline Cholesterol (mg) & $421.4 \pm 203.5$ & $552.7 \pm 431.4$ & 0.13 & $247.7 \pm 160.6$ & $231.3 \pm 160.6$ & -0.07 \\
\hline Water (g) & $3052.8 \pm 1225.3$ & $3019.5 \pm 922.4$ & 0.00 & $2485.8 \pm 703.3$ & $2887 \pm 725.0$ & 0.10 \\
\hline Vitamin A (mcg) & $1458.3 \pm 1098.2$ & $1617.2 \pm 1594.5$ & 0.07 & $1359.4 \pm 857.7$ & $1621.2 \pm 857.7$ & 0.23 \\
\hline Vitamin B1 (mg) & $1.5 \pm 0.6$ & $1.8 \pm 0.8$ & 0.20 & $1.2 \pm 0.3$ & $1.5 \pm 0.6$ & 0.23 \\
\hline Vitamin B2 (mg) & $2.4 \pm 1$ & $2.7 \pm 1.2$ & 0.16 & $1.7 \pm 0.5$ & $1.9 \pm 1.8$ & 0.14 \\
\hline Vitamin B6 (mg) & $2.5 \pm 0.9$ & $2.9 \pm 1.2$ & 0.16 & $1.9 \pm 0.7$ & $2.4 \pm 0.7$ & 0.26 \\
\hline Vitamin B12 (mcg) & $5.9 \pm 3.9$ & $7.35 \pm 4.61$ & 0.17 & $3.2 \pm 2.3$ & $3.89 \pm 2.33$ & 0.13 \\
\hline Vitamin a C (mg) & $123.5 \pm 90.6$ & $150.8 \pm 81.3$ & 0.21 & $130.9 \pm 78.2$ & $185.4 \pm 78.2$ & ${ }^{*} 0.38$ \\
\hline Vitamin D (mcg) & $3.7 \pm 3.3$ & $5.3 \pm 4.4$ & 0.24 & $3.0 \pm 2.7$ & $4.2 \pm 2.7$ & 0.12 \\
\hline Vitamin E (mg) & $13.0 \pm 5.1$ & $16.5 \pm 8.0$ & ${ }^{*} 0.25$ & $10.7 \pm 3.7$ & $11.4 \pm 3.6$ & 0.05 \\
\hline Foliate (mcg) & $422.6 \pm 204.5$ & $467.6 \pm 174.5$ & 0.15 & $357.9 \pm 122.8$ & $386.7 \pm 122.8$ & 0.23 \\
\hline Sodium (mg) & $2757.0 \pm 1134.0$ & $2886.0 \pm 1368.5$ & 0.03 & $1869.1 \pm 760.4$ & $1472.9 \pm 760.4$ & -0.26 \\
\hline Potassium (mg) & $3971.6 \pm 1293.5$ & $4484.9 \pm 1212.9$ & ${ }^{*} 0.25$ & $3328.6 \pm 935.8$ & $4000.0 \pm 935.8$ & ${ }^{*} 0.38$ \\
\hline Calcium (mg) & $1309.89 \pm 618.73$ & $1227.7 \pm 426.0$ & -0.02 & $896.8 \pm 315.6$ & $900.1 \pm 315.6$ & 0.02 \\
\hline Phosphorus (mg) & $1874.4 \pm 586.1$ & $2117.6 \pm 799.1$ & 0.17 & $1253.5 \pm 311.9$ & $1419.0 \pm 311.9$ & 0.32 \\
\hline Magnesium (mg) & $469.7 \pm 158.3$ & $553.3 \pm 210.3$ & 0.17 & $352.1 \pm 95.9$ & $447.9 \pm 95.9$ & ${ }^{*} 0.38$ \\
\hline Iron (mg) & $15.42 \pm 5.00$ & $19.6 \pm 7.5$ & ${ }^{*} 0.32$ & $13.1 \pm 4.2$ & $14.6 \pm 4.2$ & 0.24 \\
\hline Zinc (mg) & $13.4 \pm 4.3$ & $15.9 \pm 6.4$ & ${ }^{*} 0.25$ & $9.7 \pm 2.4$ & $10.5 \pm 2.4$ & 0.12 \\
\hline Copper (mcg) & $1.8 \pm 0.8$ & $2.3 \pm 1.0$ & ${ }^{*} 0.32$ & $1.5 \pm 0.5$ & $2.1 \pm 0.5$ & ${ }^{*} 0.40$ \\
\hline Manganese (mg) & $7.5 \pm 5.0$ & $8.0 \pm 5.4$ & 0.11 & $5.9 \pm 2.3$ & $6.3 \pm 2.3$ & 0.13 \\
\hline lodine (mcg) & $66.5 \pm 59.6$ & $65.1 \pm 33.0$ & 0.12 & $38.9 \pm 17.4$ & $49.4 \pm 17.4$ & 0.16 \\
\hline
\end{tabular}

* Statistical significance if $p<0.05$.

$r$ - Spearman's range correlation coefficient; $x$ - the arithmetic mean; SD - Standard Deviation; SFA - saturated fatty acids; MUFA - monounsaturated fatty acids; PUFA polyunsaturated fatty acids.

Table 2 presents the comparison of the content of macro- and micronutrients per 1,000 kcal in the diet of the studied women and men depending on the level of climbing declared. There was a statistically significant positive correlation of protein content $(r=0.22)$, vitamin $B 2(r=0.23)$, vitamin $B 6(r=0.2)$, vitamin $B 12(r=0.21)$, vitamin $D$ $(r=0.21)$, phosphorus $(r=0.25)$, magnesium $(r=0.24)$, iron (0.21) and copper $(r=0.23)$, as well as a statistically 
significant negative correlation between saturated fatty acids content $(r=-0.22)$ and the climbing level of study participants.

Table 2. Comparison of nutrients, vitamins and minerals per 1,000 kcal of the diet of the studied men and women depending on their climbing level

\begin{tabular}{|c|c|c|c|c|c|}
\hline \multirow[t]{2}{*}{ Component } & Beginner group $(n=12)$ & $\begin{array}{l}\text { Intermediate group ( } \mathrm{n} \\
\qquad=40 \text { ) }\end{array}$ & Advanced group $(n=35)$ & Elite group $(n=14)$ & \multirow[t]{2}{*}{ r } \\
\hline & $\mathrm{x} \pm \mathrm{SD}$ & $\mathrm{x} \pm \mathrm{SD}$ & $\mathrm{x} \pm \mathrm{SD}$ & $\mathrm{x} \pm \mathrm{SD}$ & \\
\hline Energy (kcal) & $2,311.6 \pm 454.9$ & $2,249.0 \pm 638.9$ & $2,545.2 \pm 848.4$ & $2,391.2 \pm 426.4$ & 0.11 \\
\hline Protein (g) & $37.2 \pm 5.0$ & $42.61 \pm 8.81$ & $42.3 \pm 10.7$ & $47.6 \pm 9.6$ & ${ }^{*} 0.22$ \\
\hline Carbohydrates (g) & $127.3 \pm 18.7$ & $128.8 \pm 18.5$ & $128.2 \pm 25.0$ & $130.4 \pm 17.7$ & 0.06 \\
\hline Fibre (g) & $13.8 \pm 6.9$ & $12.0 \pm 4.4$ & $13.4 \pm 4.6$ & $13.8 \pm 3.5$ & 0.17 \\
\hline Lactose (g) & $4.4 \pm 2.8$ & $6.0 \pm 4.9$ & $4.6 \pm 3.5$ & $4.6 \pm 4.2$ & -0.11 \\
\hline Fat (g) & $42.3 \pm 7.3$ & $37.9 \pm 7.3$ & $39.0 \pm 8.9$ & $34.7 \pm 6.7$ & -0.17 \\
\hline SFA (g) & $14.5 \pm 2.9$ & $14.2 \pm 3.2$ & $13.6 \pm 4.3$ & $11.9 \pm 4.1$ & * -0.22 \\
\hline MUFA (g) & $16.2 \pm 3.8$ & $13.3 \pm 3.5$ & $14.7 \pm 4.2$ & $12.4 \pm 3.7$ & -0.09 \\
\hline PUFA (g) & $7.8 \pm 3.2$ & $6.2 \pm 2.4$ & $7.01 \pm 2.51$ & $6.1 \pm 2.4$ & -0.02 \\
\hline Cholesterol (mg) & $141.8 \pm 90.2$ & $151.6 \pm 58.9$ & $164.9 \pm 118.4$ & $194.9 \pm 93.5$ & 0.10 \\
\hline Water (g) & $1,240.5 \pm 231.8$ & $1,257.7 \pm 436.5$ & $1,258.5 \pm 503.9$ & $1,277.9 \pm 331.9$ & 0.00 \\
\hline Vitamin A (mcg) & $581.1 \pm 273.3$ & $652.0 \pm 431.7$ & $720.1 \pm 798.2$ & $636.9 \pm 492.7$ & -0.01 \\
\hline Vitamin B1 (mg) & $0.7 \pm 0.1$ & $0.6 \pm 0.2$ & $0.68 \pm 0.2$ & $0.74 \pm 0.2$ & 0.16 \\
\hline Vitamin B2 (mg) & $0.8 \pm 0.2$ & $0.9 \pm 0.2$ & $1.0 \pm 0.3$ & $1.1 \pm 0.3$ & ${ }^{*} 0.23$ \\
\hline Vitamin B6 (mg) & $1.0 \pm 0.2$ & $1.0 \pm 0.3$ & $1.1 \pm 0.34$ & $1.3 \pm 0.4$ & ${ }^{*} 0.20$ \\
\hline Vitamin B12 (mcg) & $1.7 \pm 1.0$ & $2.1 \pm 1.2$ & $2.4 \pm 2.0$ & $3.0 \pm 1.7$ & ${ }^{*} 0.21$ \\
\hline Vitamin a C (mg) & $75.5 \pm 44.8$ & $52.9 \pm 35.4$ & $69.1 \pm 42.0$ & $72.7 \pm 41.9$ & 0.10 \\
\hline Vitamin D (mcg) & $1.5 \pm 1.1$ & $1.5 \pm 1.3$ & $1.7 \pm 1.7$ & $2.9 \pm 2.2$ & ${ }^{*} 0.21$ \\
\hline Vitamin E (mg) & $5.9 \pm 1.6$ & $5.23 \pm 1.8$ & $6.2 \pm 2.1$ & $5.6 \pm 2.5$ & 0.08 \\
\hline Foliate (mcg) & $181.9 \pm 68.1$ & $178.2 \pm 69.3$ & $175.7 \pm 56.2$ & $203.5 \pm 73.7$ & 0.07 \\
\hline Sodium (mg) & $994.2 \pm 350.6$ & $1,043.4 \pm 293.4$ & $985.8 \pm 367.2$ & $964.1 \pm 515.5$ & -0.10 \\
\hline Potassium (mg) & $1,725.3 \pm 387.7$ & $1,645.6 \pm 419.7$ & $1,772.7 \pm 471.1$ & $1,891.3 \pm 433.2$ & 0.18 \\
\hline Calcium (mg) & $418.3 \pm 101.6$ & $528.8 \pm 194.2$ & $478.3 \pm 111.8$ & $413.8 \pm 75.4$ & -0.07 \\
\hline Phosphorus (mg) & $644.8 \pm 106.1$ & $729.7 \pm 135.9$ & $754.0 \pm 153.9$ & $800.5 \pm 177.8$ & ${ }^{*} 0.25$ \\
\hline Magnesium (mg) & $181.4 \pm 43.3$ & $188.7 \pm 44.5$ & $213.6 \pm 64.7$ & $220.0 \pm 51.6$ & *0.24 \\
\hline Iron (mg) & $7.1 \pm 1.9$ & $6.3 \pm 1.4$ & $7.2 \pm 1.7$ & $7.7 \pm 2.0$ & ${ }^{*} 0.21$ \\
\hline Zinc (mg) & $5.2 \pm 0.8$ & $5.3 \pm 1.1$ & $5.6 \pm 1.3$ & $6.0 \pm 1.5$ & 0.19 \\
\hline Copper (mcg) & $0.8 \pm 0.3$ & $0.7 \pm 0.2$ & $0.9 \pm 0.3$ & $1.0 \pm 0.3$ & ${ }^{*} 0.23$ \\
\hline Manganese (mg) & $3.1 \pm 1.3$ & $3.0 \pm 1.7$ & $3.1 \pm 1.7$ & $3.1 \pm 1.1$ & 0.05 \\
\hline lodine (mcg) & $21.0 \pm 11.5$ & $25.4 \pm 20.2$ & $23.9 \pm 15.6$ & $30.6 \pm 15.5$ & 0.14 \\
\hline
\end{tabular}

* Statistical significance if $p<0.05$.

$\mathrm{r}$ - Spearman's range correlation coefficient; $\mathrm{x}$ - the arithmetic mean; SD - Standard Deviation.

Table 3 presents the comparison of the values of anthropometric parameters of the participants depending on their climbing level. Male participants who belonged to the advanced group were characterized by higher values of the parameters of: body mass, percentage of water in the body and lean body mass, while lower value of the index of visceral tissue content, and a lower percentage of fat in the body in comparison with men from the beginnerintermediate group. Among the women in the advanced group, there was a higher value of various parameters such 
as: body weight, percentage of fat in the body, index of visceral tissue content; while the percentage of water in the body was lower as compared to the beginner-intermediate group. In both groups - women and men - participants from the advanced group were characterized by a higher average BMI, compared to participants in the beginnerintermediate group.

Table 3. Comparison of the values of anthropometric parameters of the studied women and men depending on their climbing level

\begin{tabular}{|c|c|c|c|c|c|c|}
\hline \multirow{3}{*}{ Parameter } & \multicolumn{3}{|c|}{ Men } & \multicolumn{3}{|c|}{ Women } \\
\hline & $\begin{array}{l}\text { beginner- } \\
\text { intermediate group } \\
\quad(n=30)\end{array}$ & $\begin{array}{l}\text { advanced group } \\
\qquad(n=35)\end{array}$ & $r$ & $\begin{array}{l}\text { beginner-intermediate } \\
\text { group }(n=22)\end{array}$ & $\begin{array}{l}\text { advanced group } \\
\qquad(n=14)\end{array}$ & r \\
\hline & $\mathrm{x} \pm \mathrm{SD}$ & $\mathrm{x} \pm \mathrm{SD}$ & & $\mathrm{x} \pm \mathrm{SD}$ & $\mathrm{x} \pm \mathrm{SD}$ & \\
\hline Age & $26.2 \pm 4.8$ & $27.8 \pm 6.1$ & 0.08 & $25.4 \pm 4.0$ & $25.4 \pm 3.5$ & -0.01 \\
\hline Height (m) & $1.8 \pm 0.1$ & $1.8 \pm 0.1$ & 0.01 & $1.7 \pm 0.1$ & $1.66 \pm 0.05$ & 0.07 \\
\hline Waist circumference $(\mathrm{cm})$ & $78.5 \pm 4.5$ & $79.4 \pm 4.2$ & 0.13 & $69.0 \pm 5.4$ & $69.39 \pm 3.90$ & 0.21 \\
\hline Hip circumference $(\mathrm{cm})$ & $94.8 \pm 5.1$ & $95.6 \pm 5.5$ & 0.12 & $89.4 \pm 5.6$ & $89.4 \pm 8.0$ & 0.1 \\
\hline Fat percentage (\%) & $12.9 \pm 11.6$ & $10.0 \pm 3.6$ & -0.14 & $19.3 \pm 5.3$ & $20.7 \pm 3.3$ & 0.17 \\
\hline Body weight (kg) & $71.1 \pm 6.2$ & $72.4 \pm 7.5$ & 0.12 & $56.3 \pm 6.5$ & $58.2 \pm 5.3$ & 0.16 \\
\hline Basal Metabolic Rate (kcal) & $1,847.9 \pm 165.6$ & $1,840.4 \pm 378.2$ & 0.12 & $1,300.5 \pm 301.1$ & $1,307.9 \pm 353.0$ & 0.13 \\
\hline Water percentage (\%) & $64.1 \pm 4.0$ & $65.3 \pm 3.5$ & 0.14 & $60.0 \pm 4.6$ & $58.7 \pm 2.7$ & -0.16 \\
\hline Visceral fat tissue indicator & $1.9 \pm 1.2$ & $1.7 \pm 1.2$ & -0.05 & $1.3 \pm 0.6$ & $1.4 \pm 0.9$ & 0.07 \\
\hline Bone mass (kg) & $3.2 \pm 0.3$ & $3.3 \pm 0.3$ & 0.16 & $2.31 \pm 0.23$ & $2.3 \pm 0.2$ & 0.08 \\
\hline Fat-free body mass (kg) & $60.1 \pm 5.8$ & $62.0 \pm 6.9$ & 0.19 & $43.01 \pm 4.45$ & $43.7 \pm 3.5$ & 0.06 \\
\hline $\mathrm{BMI}\left(\mathrm{kg} / \mathrm{m}^{2}\right)$ & $22.9 \pm 1.8$ & $23.1 \pm 1.7$ & 0.03 & $19.73 \pm 4.79$ & $21.0 \pm 1.3$ & 0.14 \\
\hline WHR & $0.8 \pm 0.1$ & $0.8 \pm 0.04$ & 0.08 & $0.8 \pm 0.1$ & $0.8 \pm 0.1$ & -0.11 \\
\hline
\end{tabular}

$\mathrm{r}$ - Spearman's range correlation coefficient; $\mathrm{x}$ - the arithmetic mean; SD - Standard Deviation.

Table 4 presents the comparison of micro- and macroelements recommendations realization in the diet of the participants based on their climbing level. Among all participants deficient intake of vitamin $D$ and iodine was observed. Dietary supply of the rest of vitamins and minerals was sufficient for Al or EAR recommendation level. In the diets of both male and female participants, the supply of phosphorus, copper and manganese has been exceeded. High intake with the diet of vitamin A among studied climbers was observed. Also, high intake of vitamin B12 with the diet among male climbers was recorded.

Table 4. Comparison of the implementation of the recommendation for micro- and macro elements in the diets of the studied women and men depending on the climbing level

\begin{tabular}{|c|c|c|c|c|c|c|c|c|c|c|}
\hline \multirow[b]{2}{*}{ Component } & \multicolumn{5}{|c|}{ Men } & \multicolumn{5}{|c|}{ Women } \\
\hline & EAR & $\begin{array}{l}\text { begin- } \\
\text { ner-inter- } \\
\text { mediate } \\
\text { group }\end{array}$ & $\begin{array}{c}\text { percent } \\
\text { recom- } \\
\text { mendation } \\
\text { realization }\end{array}$ & $\begin{array}{c}\text { advanced } \\
\text { group }\end{array}$ & $\begin{array}{c}\text { percent } \\
\text { recom- } \\
\text { mendation } \\
\text { realization }\end{array}$ & EAR & $\begin{array}{l}\text { begin- } \\
\text { ner-inter- } \\
\text { mediate } \\
\text { group }\end{array}$ & $\begin{array}{l}\text { percent } \\
\text { recom- } \\
\text { mendation } \\
\text { realization }\end{array}$ & $\begin{array}{c}\text { advanced } \\
\text { group }\end{array}$ & $\begin{array}{c}\text { percent } \\
\text { recom- } \\
\text { mendation } \\
\text { realization }\end{array}$ \\
\hline 1 & 2 & 3 & 4 & 5 & 6 & 7 & 8 & 9 & 10 & 11 \\
\hline Vitamin A (mcg) & 630.0 & $1,458.30$ & 231 & $1,617.10$ & 257 & 530.0 & $1,359.4$ & 257 & $1,621.20$ & 306 \\
\hline Vitamin B1 (mg) & 1.1 & 1.50 & 138 & 1.80 & 166 & 0.9 & 1.2 & 129 & 1.50 & 161 \\
\hline Vitamin B2 (mg) & 1.1 & 2.40 & 215 & 2.70 & 246 & 0.9 & 1.7 & 183 & 1.90 & 211 \\
\hline
\end{tabular}




\begin{tabular}{|c|c|c|c|c|c|c|c|c|c|c|}
\hline 1 & 2 & 3 & 4 & 5 & 6 & 7 & 8 & 9 & 10 & 11 \\
\hline Vitamin B6 (mg) & 1.1 & 2.50 & 227 & 2.90 & 261 & 1.1 & 1.9 & 173 & 2.40 & 215 \\
\hline Vitamin B12 (mcg) & 2.0 & 5.90 & 295 & 7.40 & 368 & 2.0 & 3.2 & 161 & 3.90 & 195 \\
\hline Vitamin a C (mg) & 95.0 & 123.50 & 130 & 150.80 & 159 & 70.0 & 130.9 & 187 & 185.43 & 265 \\
\hline Vitamin D (mcg) & $15.0^{*}$ & 3.69 & 24 & 5.30 & 36 & $15.0^{*}$ & 3.0 & 20 & 4.20 & 28 \\
\hline Vitamin E (mg) & $12.0^{*}$ & 13.00 & 108 & 16.50 & 138 & $10.0^{*}$ & 10.7 & 107 & 11.40 & 114 \\
\hline Foliate (mcg) & 320.0 & 422.60 & 132 & 467.60 & 146 & 320.0 & 357.9 & 112 & 386.70 & 121 \\
\hline Sodium (mg) & $1,500.0^{*}$ & $2,757.00$ & 184 & $2,886.00$ & 192 & $1,500.0^{*}$ & $1,869.1$ & 125 & $1,472.90$ & 98 \\
\hline Potassium (mg) & $3,500.0^{*}$ & $3,971.60$ & 113 & $4,484.90$ & 128 & $3,500.0^{*}$ & $3,328.6$ & 95 & $4,000.00$ & 114 \\
\hline Calcium (mg) & 800.0 & $1,309.90$ & 164 & $1,227.70$ & 155 & 800.0 & 896.8 & 112 & 900.10 & 113 \\
\hline Phosphorus (mg) & 580.0 & $1,874.40$ & 323 & $2,117.60$ & 365 & 580.0 & $1,253.5$ & 216 & $1,419.00$ & 245 \\
\hline Magnesium (mg) & 350.0 & 469.70 & 134 & 553.32 & 158 & 265.0 & 352.1 & 133 & 447.90 & 169 \\
\hline Iron (mg) & 6.0 & 15.40 & 257 & 19.60 & 327 & 8.0 & 13.1 & 163 & 14.60 & 182 \\
\hline Zinc (mg) & 9.4 & 13.40 & 143 & 15.90 & 169 & 6.5 & 9.7 & 149 & 10.50 & 161 \\
\hline Copper (mcg) & 0.7 & 1.80 & 257 & 2.30 & 329 & 0.7 & 1.5 & 217 & 2.10 & 293 \\
\hline Manganese (mg) & $2.3^{*}$ & 7.50 & 324 & 8.00 & 350 & $1.8^{*}$ & 5.9 & 327 & 6.30 & 352 \\
\hline lodine (mcg) & 95.0 & 66.50 & 70 & 65.10 & 69 & 95.0 & 38.9 & 41 & 49.40 & 52 \\
\hline
\end{tabular}

EAR - Estimated Average Requirement.

${ }^{*} \mathrm{Al}$ - Adequate Intake.

\section{Discussion}

Despite the growing popularity of sport climbing and knowledge about the impact of proper nutrition on the effectiveness of training in the available literature, there is no research assessing the relationship between climbing level and nutritional status and nutritional intake. However, some researchers have assessed the nutritional intake and nutritional status of climbers.

In the study (Kemmler et al., 2006) involving 15 elite female athletes training sport climbing, a similar magnesium content was estimated ( $445.7 \pm 103.3$ vs. $447.86 \pm 95.87 \mathrm{mg}$ ), iron (15.3 \pm 4.6 vs. $14.85 \pm 4.18 \mathrm{mg}$ ), vitamin B1 ( $1.31 \pm 0.31$ vs. $1.89 \pm 0.54 \mathrm{mg}$ ), vitamin C (154.6 \pm 87.8 vs. $185.45 \pm 78.19 \mathrm{mg}$ ) in their diets, as in the diets of climbers in the advanced group from own study. However, the diets of climbers from the own study were characterized by a lower content of calcium $(1,223 \pm 421 \mathrm{vs.} 900.06 \pm 315.7 \mathrm{mg})$ and phosphorus $(1,630 \pm 504 \mathrm{vs}$. $1418 \pm 311.85 \mathrm{mg}$ ). These minerals in the study of W. Kemmler et al. (2006) were evaluated as correlating with bone density, an important parameter in injury-prone sports, such as climbing. Diets of women from the advanced group contained significantly more vitamin D (4.18 \pm 2.72 vs. $1.69 \pm 0.6 \mathrm{mcg})$ and potassium $(4,000.00 \pm 935.84$ vs. 3,603 $\pm 1,025 \mathrm{mg}$ ). In the W. Kemmler et al. study, there were no significant differences in the nutrient content of the diets between the test group and the control group, consisting of women of similar age and BMI, but with much lower physical activity. In contrast to our own study, in which lower vitamin $\mathrm{C}, \mathrm{Mg}, \mathrm{K}$ content in the diet correlated with a lower advancement level.

In another study (Pilis et al., 2014) evaluating the nutritional contents in the diet of weightlifters, in which anaerobic work prevails, the content of micronutrients - zinc and copper - were estimated. In own study, zinc and copper content in the diet correlated with a higher level of climbing. With a similar average energy value of powerlifter diets and diets of people from the group of advanced climbers (2,720.3 kcal vs. 3,327 kcal), a higher content of Zn (13.02 vs. $15.9 \mathrm{mg}$ ) and $\mathrm{Cu}(1.4 \mathrm{vs.} 2.3 \mathrm{mg}$ ) were observed in the diets of people training climbing. 
In the study by K. Pilis et al., in contrast to our results, there were no significant correlations between the content of zinc and copper in the diet and the level of physical activity in the studied group. Similar content of $\mathrm{Cu}(1,874 \mathrm{mcg})$ and $\mathrm{Mn}(3,200.2 \mathrm{mg})$, with a similar energy value of the diet $(2,215.2 \mathrm{kcal})$ as in this study, was estimated in another group of athletes practicing sports characterized by anaerobic efforts (judo and sprint) (Maynar et al., 2018).

In the study by W. Kozirok and E. Babicz-Zielińska (2013), the water intake per day was assessed with particular emphasis on the time of training in the group of 396 athletes, including approximately 130 people training strength sports. Approximately $60 \%$ of the strength training participants reported consumption of nearly one to two liters of fluids during training. Both the diets of men and women from own study, regardless of the level of advancement, similarly to the athletes' diets assessed, were characterized by a high content of liquids, above two liters per day. Compared to the Czech climbers (Juriková, Alexová, Pluháčková, 2015) (9 women and 12 men), the group of Polish athletes had a higher percentage of diets that contained more than two liters of fluids a day ( 84 vs. $60 \%$ ).

E.E. Neufeld and M.C. Meyers (2018), as in the own study, assessed the daily content of nutrients in a group of 50 rock climbers, based on the record of consumption from three days. The content of nutrients in the diets of women from own study (beginner-intermediate group and advanced group) and women practicing rock climbing did not meet the standards for vitamin D intake (respectively: $3.0,4.2$ and $3.8 \mathrm{vs.} 15 \mathrm{mcg}$ ) and potassium $(3,328.6$, $4,000.0$ and 1,992.2 vs. 4,700 mg). In own-study group, insufficient iodine content was additionally assessed (38.9, 49.4 vs. $95 \mathrm{mcg}$ ), which was not shown in the study by Neufeld and Meyers. In addition, the diets of women practicing rock climbing did not meet the standards for vitamin E (5.7 vs. $15.0 \mathrm{mg}$ ) and $\mathrm{Mg}$ intake (219.7 vs. $310 \mathrm{mg}$ ) and significantly exceeded the norm for the sodium content in the diet by approx. $80 \%$ (2,689.1 vs. 1,500 mg). In our own study only in the diets of participants classified into the beginner-intermediate group average sodium content exceeded this norm by $25 \%$ (1,869.1 vs. $1,500 \mathrm{mg}$ ).

The implementation of standards in both groups of men was similar. Insufficient content of nutrients concerned vitamin D (group of beginner-intermediate and advanced - 3.69, advanced group - 5.3, group of rock climbers $3.5 \pm 3.8$ vs. $15 \mathrm{mcg}$ ), potassium (3,971.6; 4,448.9; $2,467.3$ vs. $4,700 \mathrm{mg})$, and excessive sodium $(2,757 ; 2,886.0$; $2,658.5$ vs. $1,500 \mathrm{mg})$, vitamin $\mathrm{B} 2(2.4 ; 2.7 ; 1.8$ vs. $1.3 \mathrm{mg})$ and iron $(15.4 ; 19.6 ; 16.2$ vs. $8.0 \mathrm{mg})$. In the diets of men from our study, higher content of these nutrients and higher, excessive supply with the diet were estimated. Assessed sodium content was higher by $7 \%$ and $15 \%$, in beginner-intermediate and advanced groups, respectively; the standard for vitamin B2 intake was exceeded by $46 \%$ and $79 \%$ and Fe content in advanced group exceeded recommendations by $43 \%$.

In addition, male group diets from the E.E. Neufeld and M.C. Meyers (2018) study did not meet the established fiber recommendation ( $27.6 \pm 12.3$ vs. $38 \mathrm{~g}$ ). Its content was similar to the average value of diets from the beginnerintermediate group from our study $(27.1 \pm 13.4 \mathrm{~g})$, where the intake of this component positively correlated with the advancement level.

The content of macronutrients in the diet of athletes, i.e. proteins, fats and carbohydrates, is important in the development of muscle mass, increasing training efficiency and proper regeneration. In 2016, the Academy of Nutrition and Dietetics, Dietitians of Canada and American College of Sports Medicine indicated the intake of protein at $1.2-2 \mathrm{~g} \cdot \mathrm{kg}^{-1} \mathrm{BW} \cdot$ day $^{-1}$ and carbohydrates at 3-12 $\mathrm{g} \cdot \mathrm{kg}^{-1} \mathrm{BW} \cdot$ day-1 as appropriate for athletes. Emphasizing that the higher level of their consumption should depend on the advancement, quantity, and quality of training (Thomas, Erdman, Burke, 2016). The authors of nutritional recommendation for practicing one of the climbing types - bouldering, proposed a slightly higher level of protein intake, i.e. $1.4-2 \mathrm{~g} \cdot \mathrm{kg}^{-1} \mathrm{BW} \cdot \mathrm{day}^{-1}$ for this 
group of athletes (Smith, Storey, Ranchordas, 2017). Additionally, according to other researches results (Tipton, Jeukendrup, Hespel, 2007), consuming carbohydrates at the level of $5 \mathrm{~g} / \mathrm{kg}$ BW may be associated with the proper maintenance of glycogen stores in the muscles.

In our own study, only diets of men were characterized by such protein content per kilogram of body weight $\left(1.57 \mathrm{~g} \cdot \mathrm{kg}^{-1} \mathrm{BW} \cdot\right.$ day $^{-1}$ and $1.74-2 \mathrm{~g} \cdot \mathrm{kg}^{-1} \mathrm{BW} \cdot$ day $\left.^{-1}\right)$. The diets of women contained approximately $1.3 \mathrm{~g} \cdot \mathrm{kg}^{-1} \mathrm{BW}$. day ${ }^{-1}$ protein. These contents did not exceed $2 \mathrm{~g} \cdot \mathrm{kg}^{-1} \mathrm{BW} \cdot$ day $^{-1}$. Both diets of women and men, regardless of the climbing level, on average contain from about $4.4 \mathrm{~g} \cdot \mathrm{kg}^{-1} \mathrm{BW} \cdot$ day $^{-1}$ to about $4.73 \mathrm{~g} \cdot \mathrm{kg}^{-1} \mathrm{BW} \cdot \mathrm{day}^{-1}$. carbohydrates. In the advanced group, regardless of sex, higher average content of proteins and carbohydrates per kg body weight was assessed. The lower intake of protein in the studied climbers' diets, than the recommendations for bouldering (Smith et al., 2017), may result from the heterogeneity of the studied group in terms of training types of climbing, such as bouldering, lead climbing, speed, and the advancement level.

In addition, the content of macronutrients in diets may be the result of lower values of energy in diets of some climbers in relation to the total daily requirement. The authors of studies assessing the body composition and diets of people practicing climbing have been observing the use of energy-reduced diets in this group of athletes. In order to reduce the body fat percentage and improve the strength-to-weight ratio, athletes reduced energy supply, exposing themselves to nutritional deficiencies (Stanković, Ignjatović, Puletić, Raković, Mladenović Ćirić, 2013). In addition, a significant majority of participants (about 98\%) of their research did not practice climbing on a professional level, requiring extremely intensified training and resulting in the supply of protein and carbohydrates at the upper limits of the standards. Half of the participants were included in the beginner-intermediate group, therefore the average protein consumption at a low level in relation to the recommendations seems to be adequate to the level and advancement of training. In addition, climbers' expectations of maintaining low body mass and low body fat content, as well as avoiding excessive muscle hypertrophy, increasing their own weight, do not require increased protein supply to approx. $2 \mathrm{~g} \cdot \mathrm{kg}^{-1} \mathrm{BW} \cdot \mathrm{day}^{-1}$. In addition to dietary proteins, athletes' diets contained smaller amounts of carbohydrates. Lower intake of protein with such a supply of calories and carbohydrates seems adequate, due to the possibility of muscle protein regeneration. Optimizing this process with a higher protein intake would require an increased supply of carbohydrates (Tipton et al., 2007).

In own study lower body fat content and BMI index characterized male climbers from advanced group compared to beginner-intermediate group. These results are similar to the research led by M.F. Novoa-Vignau, O. Salas-Fraire, K. Salas-Longoria, G. Hernández-Suárez, M. Menchaca-Pérez (2017), where differences between elite, recreational climbers and non-climbers group were observed. Similar fat content in advanced group of climbers were observed in research led by C. Mermier, J. Janot, D. Parker, J. Swan (2000) and W. Kemmler et al (2006), but participants of the other studies presented lower values such us $6.0 \pm 0.9$ (Sheel, Seddon, Knight, McKenzie, Warburton, 2003), 6.2 (Schöffl, Möckel, Köstermeyer, Roloff, Küpper, 2006) and $5.8 \pm 1.8$ (Michailov, Mladenov, Schöffl, 2009). In the advanced female group of climbers in our own study body weight, BMI value and fat content were higher compared to beginner-intermediate group. Those results are similar to those obtained in the research led by C. Mermier et al. (2000). In the study led by P. Watts, D. Martin, S. Durtschi (1993) and M. Michailov, L. Mladenov, I. Schöffl (2009), world class female boulderers characterized with much lower fat content (9.6 \pm 1.9 and $16.6 \pm 3.6$ respectively). The participants of the studies where the fat content values were lower represented much higher level of advancement compared to the advanced group from the own study, which could be the reason for such differences. It is suggested that the performance in sport climbing is affected by many factors (Michailov, 
Mladenov, Schöffl, 2009), so anthropometric parameters, such us fat content themselves, may not be the main determinant of the level of advancement in sport climbing.

\section{Conclusions}

The association between the level of advancement and the content of selected micro- and macronutrients in the diets of studied group of climbers was observed. The diets characterized with rather low intake of protein and carbohydrates compared to recommendations for athletes. That can be explained with overall low energy intake that is often practiced by sport climbing representatives to maintain low body weight. Further studies must be conducted to create nutritional recommendations specific for this discipline representatives. The anthropometric parameters differed between participants representing various level of advancement, but the differences were not statistically significant.

\section{Acknowledgements}

We would like to acknowledge the help of members of Student Science Club from Dietetic Department of Wroclaw Medical University and Magdalena Narbutowicz during the data collection process.

\section{References}

Bertuzzi, R.C., Franchinim, E., Kokubun, E., Kiss, M.A. (2007). Energy system contributions in indoor rock climbing. Eur J Appl Physiol, 101, 293-300.

Cohen, J.A. (1992). Power primer. Psychol Bull, 112, 155-159.

Ginszt, M., Goniewicz, M., Ginszt, A. (2012). Analiza przyczyn i następstw urazów u dzieci i młodzieży uprawiających wspinaczkę sportowa. Hygeina Public Health, 47 (1), 23-27.

Ginszt, M., Michalak-Wojnowska, M., Gawda P., Wojcierowska-Litwin, M., Korszeń-Pilecka, I., Kusztelak, M., Muda, R. (2018). ACTN3 Genotype in professional sport climbers. J Strength Cond Res, 32, 1311-1315.

Haciski, P. (2013). Jura 2. Warszawa: RING.

Juriková, J., Alexová, M., Pluháčková, M. (2015). Do sport climbers need education in their eating habits? Zeszyty Naukowe Wyższej Szkoły Humanitas. Pedagogika, 11, 111-118.

Kemmler, W. Roloff, I., Baumann, H., Schöffl, V., Weineck, J., Kalender, W., Engelke, K. (2006). Effect of exercise, body composition, and nutritional intake on bone parameters in male elite rock climbers. Int J Sport Med, 27, 653-659.

Kozirok, W., Babicz-Zielińska, E. (2013). Ocena spożycia wody i napojów przez zawodników różnych dyscyplin sportowych. Probl Hig Epidemiol, 94, 262-265.

Kunachowicz, H., Nadolna, I., Przygoda, B., Iwanow, K. (2005). Tabele składu i wartości odżywczej żywności. Warszawa: Wyd Lek PZWL.

Lutter, C., El-Sheikh, Y., Schöffl, I., Schöffl, V. (2017). Sport climbing: medical considerations for this new Olympic discipline. Br J Sports Med, 51, 2-3.

Maynar, M., Lierena, F., Bartolome, I., Alves, J., Robles, M.C., Grijota, F.J., Munoz, D. (2018). Serum concentrations of copper, chromium, manganesum, nickel and selenium in aerobic, anaerobic and mixed professional sportsmen. J Int Soc Sports Nutr, 15, 8.

Mermier, C., Janot, J., Parker, D., Swan, J. (2000). Physiological and anthropometric determinants of sport climbing performance. Br J Sports Med, 34, 359-366.

Michailov, M., Miadenov, L. Schöffl, I. (2009). Anthropometric and strength characteristic of world-class boulderers. Med Sport, 13, 231-238.

Neufeld, E.E., Meyers, M.C. (2018). Nutritional Status of rock climbers: 1286 Board\#94 May 31. Med Sci Sports Exerc, $50,303$.

Neuhof, A., Hennig, F.F., Schöffl, I., Schöffl, V. (2011). Injury risk evaluation in sport climbing. Int J Sport Med, 32, 794-800. 
Novoa-Vignau, M.F., Salas-Fraire, O., Salas-Longoria, K., Hernández-Suárez, G., Menchaca-Pérez, M. (2017). A comparison of anthropometric characteristics and somatotypes in a group of elite climbers, recreational climbers and non-climbers. Medicina Universitaria, 19, 69-73.

Pilis, K., Michalski, C., Zych, M., Pilis, A., Jelonek, J., Kaczmarzyk, A., Pilis, W. (2014). A nutritional evaluation of dietary behavior in various professional sports. Rocz Panstw Zakl Hig, 65, 227-234.

Schöffl, V.R., Möckel, M., Köstermeyer, G., Roloff, I., Küpper, T. (2006). Development of a performance diagnosis of the anaerobic strength endurance of the forearm flexor muscles in sport climbing. Int J Sports Med, 27, 205-211.

Sheel, A.W., Seddon, N., Knight, A., McKenzie, D.C., Warburton, D.E. (2003). Physiological responses to indoor rock climbing and their relationship to maximal cycle ergometry. Med Sci Sports Exerc, 35, 1225-1231.

Smith, E.J., Storey, R., Ranchordas, M.K. (2017). Nutritional Considerations for bouldering. Int J Sport Nutr Exerc Metab, $27,314-324$.

Stanković, D., Ignjatović, M., Puletić, M., Raković, A., Mladenović Ćirić, I. (2013). The nutrition of rock climbers. XVI International Scientific Conference. FIS Communications 2013 in physical education, sport and recreation and I International Scientific Conference, At Niš, Serbia.

Stanković, D., Joksimović, A., Aleksandrović, M. (2011). Relation and influences of sports climbers' specific strength on the success in sports climbing. SAJR SPER, 33, 121-131.

Thomas, T.D., Erdman, A.K., Burke, L.M. (2016). Position of the Academy of nutrition and dietetics, dietitians of Canada, and the American college of sports medicine: nutrition and athletic performance. J Acad Nutr Diet, 116, 501-28.

Tipton, K.D., Jeukendrup, A.E., Hespel, P. (2007). International Association of Athletics Federations. Nutrition for the sprinter. J Sports Sci, 25, 5-15.

Watts, P., Martin, D., Durtschi, S. (1993). Anthropometric profiles of elite male and female sport rock climbers. J of Sports Sciences, 11, 113-117.

Verhosanski, V.J., Šestakov, M.P., Novikov, P.S., Nićin, D.A. (1992). Specific power in sport. Novi Sad: Prometej \& Faculty of Physical Education.

Vigoroux, L., Quaine, F., Labarre-Vila, A., Moutet, F. (2006). Estimation of finger muscle tendon tensions and pulley forces during specific sport-climbing grip techniques. J Biomech, 39, 2583-2592.

Cite this article aS: Przeliorz-Pyszczek, A., Gołabek, K., Regulska-llow, B. (2019). Evaluation of the Relationship of the Climbing Level of Sport Climbers with Selected Anthropometric Indicators and Diet Composition. Central European Journal of Sport Sciences and Medicine, 4 (28), 15-25. DOI: 10.18276/cej.2019.4-02. 